Article

\title{
Development of a Biodegradable Electro-Insulating Liquid and Its Subsequent Modification by Nanoparticles
}

\author{
Vaclav Mentlik, Pavel Trnka* (D), Jaroslav Hornak ${ }^{(\mathbb{D})}$ and Pavel Totzauer \\ Department of Technologies and Measurement, Faculty of Electrical Engineering, University of West Bohemia, \\ 30614 Pilsen, Czech Republic; mentlik@ket.zcu.cz (V.M.); jhornak@ket.zcu.cz (J.H.); tocik@ket.zcu.cz (P.T.) \\ * Correspondence: pavel@ket.zcu.cz; Tel.: +420-377-634-518
}

Received: 23 January 2018; Accepted: 23 February 2018; Published: 27 February 2018

\begin{abstract}
The paper is focused on the possibility of replacing petroleum-based oils used as electro-insulating fluids in high voltage machinery. Based on ten years of study the candidate base oil for the central European region is rapeseed (Brassica napus) oil. Numerous studies on the elementary properties of pure natural esters have been published. An advantage of natural ester use is its easy biodegradability, tested according to OECD-301D (Organisation for Economic Co-operation and Development) standard, and compliance with sustainable development visions. A rapeseed oil base has been chosen for its better resistance to degradation in electric fields and its higher oxidation stability. The overall ester properties are not fully competitive with petroleum-based oils and therefore have to be improved. Percolation treatment and oxidation inhibition by a phenolic-type inhibitor is proposed and the resulting final properties are discussed. These resulting fluid properties are further improved using titanium dioxide $\left(\mathrm{TiO}_{2}\right)$ nanoparticles with a silica surface treatment. This fluid has properties suitable for use in sealed distribution transformers with the advantage of a lower price in comparison with other currently used biodegradable fluids.
\end{abstract}

Keywords: natural ester; titanium dioxide; resistivity; breakdown voltage; percolation treatment; antioxidant; surface treatment

\section{Introduction}

When designing a modern electrical machine, the technical aspects of the matter are not the only important ones-the environmental compatibility of the materials has become more important. Natural ester fluids have potential for industrial usage due to their good biodegradability (tested according to the OECD-301D standard [1]). A good biodegradable substance according to the standard is a substance which in the case of the contamination of soil, is naturally degraded by at least seventy percent by the soil bacteria in 28 days. This environmental property is an advantage in some technical solutions where devices require a liquid medium (for example, for cooling or to create a potential barrier to an electric field) for their operation and where there is a potential risk of soil contamination in the event of leakage [2]. Natural esters have this positive feature as they are examples of materials suitable for sustainable development applications. They can be produced with a competitive final price from local natural sources. These facts are the basic idea behind the preparation of a new electro-insulating liquid based on rapeseed oil. This liquid is expected to be competitive in its price and overall properties to the mineral-typically based electroinsulating liquids used in medium voltage transformers. There are commercial products already used in the transformers [3,4], however, still, several technical problems prevent them from being deployed. Well know are problems with their higher viscosity (a heat transfer issue) [5], high pour point [6], higher permittivity [7], low oxidation stability [8] (a hermetic design is required) and the high price of commercially produced esters, etc. This is also the reason why 
currently such fluids are deployed in Europe sporadically, mainly in headquarters or showrooms of international corporations or in specially protected areas. Less known are problems of virtually no legislative path allowing wider industrial use of natural esters, and durability problems in the terms of short high voltage impulse resistance $[9,10]$, etc. Natural esters do also have advantages, e.g., lower degree of polymerization of cellulose compared to mineral fluids [11], high flash point [12] and inherent "moisture tolerance" [13].

\section{Assessment of Natural Ester-Base Fluids for Further Development Based on Their Electrical Properties}

In central Europe there are two widely spread representative natural esters that are suitable for industrial application—rapeseed (Brassica napus) [14] and sunflower (Helianthus annuus) [15] oil. Both crops are grown in several variations all over the world. The oil gathered from the seeds is a source material for several products, electro-insulating fluids included.

The composition of natural esters provides a very useful source of information about an oil's behavior. The structure of natural esters is based on a glycerol backbone with three attached fatty acid molecules. The nature of these fatty acids is decisive for the overall properties of the oil. For example, a high number of saturated fatty acids makes the oil stable to oxidation but also prone to solidification and high viscosity, whereas, a high number of poly- and mono-unsaturated fatty acids keeps the oil in a liquid state (low viscosity), even in lower temperatures, but makes it prone to oxidation. This is described in more detail in CIGRE Brochure $\mathrm{N}^{\circ} 436$ [16].

The first step is the assessment of a better base oil for further development. Experiments based on assessing the reaction and speed of the long-term thermal and electrical ageing of insulation systems containing these natural ester oils was done to provide data for a justified choice between rapeseed and sunflower oil. The main part of the experiment involved testing the liquids in the electrode system with a liquid (rapeseed and sunflower natural ester oil) and a solid (cellulose-based paper) insulation part simulating thus part of the power transformer. Each oil was inhibited with $0.4 \mathrm{wt} \%$ of phenolic inhibitor. The basic properties of the abovementioned fluids are provided in Table 1.

Table 1. Basic and required properties of untreated sunflower and rapeseed oil.

\begin{tabular}{ccccc}
\hline Parameter & Standard & Sunflower Oil * & Rapeseed Oil * & Unit \\
\hline Density at $15{ }^{\circ} \mathrm{C}$ & ISO 3675, ISO 12185 & 0.92 & 0.917 & $\mathrm{~g} \cdot \mathrm{cm}^{-3}$ \\
Kinematic viscosity at $40{ }^{\circ} \mathrm{C}$ & ISO 3104 & 32.67 & 35.7 & $\mathrm{~mm}^{2} \cdot \mathrm{s}^{-1}$ \\
Dissipation factor at $90{ }^{\circ} \mathrm{C}$ & IEC 61620, IEC 60247 & 0.00202 & 0.0018 & - \\
Relative permittivity & IEC 60247 & 3.93 & 3.44 & - \\
Breakdown voltage & IEC 60156 & 63.77 & 61.54 & $\mathrm{kV} / 2.5 \mathrm{~mm}$ \\
Acid number & IEC 62021 & 0.042 & 0.092 & $\mathrm{mg} \mathrm{KOH} / \mathrm{g}$ \\
\hline
\end{tabular}

* The values vary with the source of the oil-depending on the purity and water content.

The experiment itself proceeded as follows: samples of solid insulation (transformer board with thickness of $0.2 \mathrm{~mm}$ ) were dried $\left(24 \mathrm{~h}\right.$, at $\left.80^{\circ} \mathrm{C}\right)$, impregnated and then inserted between the electrodes in the electrode system shown in Figure 1. The oil itself was also dried using only heat $\left(24 \mathrm{~h}, 90^{\circ} \mathrm{C}\right.$ to $80 \mathrm{ppm}$ ) before the beginning of the test. The electrode system consists of five electrodes with a diameter of $25 \mathrm{~mm}$ with rounded edges. The voltage levels for rapeseed oil were 4.3 to $7.4 \mathrm{kV}$, for sunflower oil 5.5 to $8.3 \mathrm{kV}$ for similar time to breakdowns. 


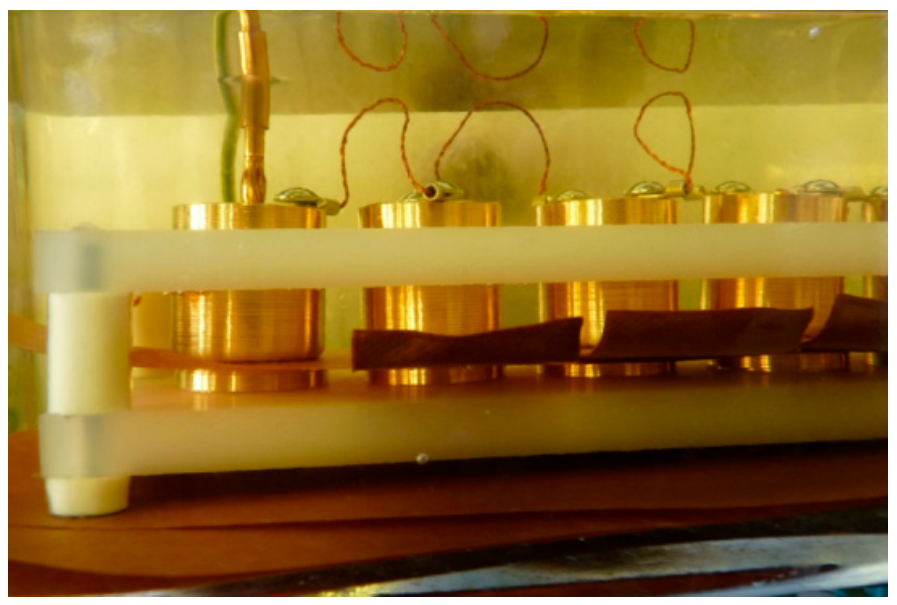

Figure 1. Electrode system for long-term electric stress.

Given the fact that oil behavior is strongly dependent on moisture [17], the whole test was performed under constant environment moisture monitoring, so the experiment itself was not affected. Table 2 shows the experimental results of the electric stress test. The comparison is made via the slope of the measured characteristics for each insulation system used, as the slope value serves as statistical indicator. The lower the slope value, the less prone to electrical stress the oil-paper system.

Table 2. Experiment results-slope comparison of measured characteristics.

\begin{tabular}{ccc}
\hline Insulation System & Stress Type & Slope Value \\
\hline Rapeseed oil + pressboard & AC $50 \mathrm{~Hz}$ & -0.884 \\
Sunflower oil + pressboard & AC $50 \mathrm{~Hz}$ & -2.048 \\
\hline
\end{tabular}

When an AC stress voltage is applied, the sunflower oil insulation system exhibits a higher rate of deterioration. The difference between the slope values (as shown in Table 2) is 1.16 which is statistically significant. From the measured characteristics (Figure 2) we can clearly state that the rapeseed oil has lower values of time to breakdowns, but the speed of degradation is lower.

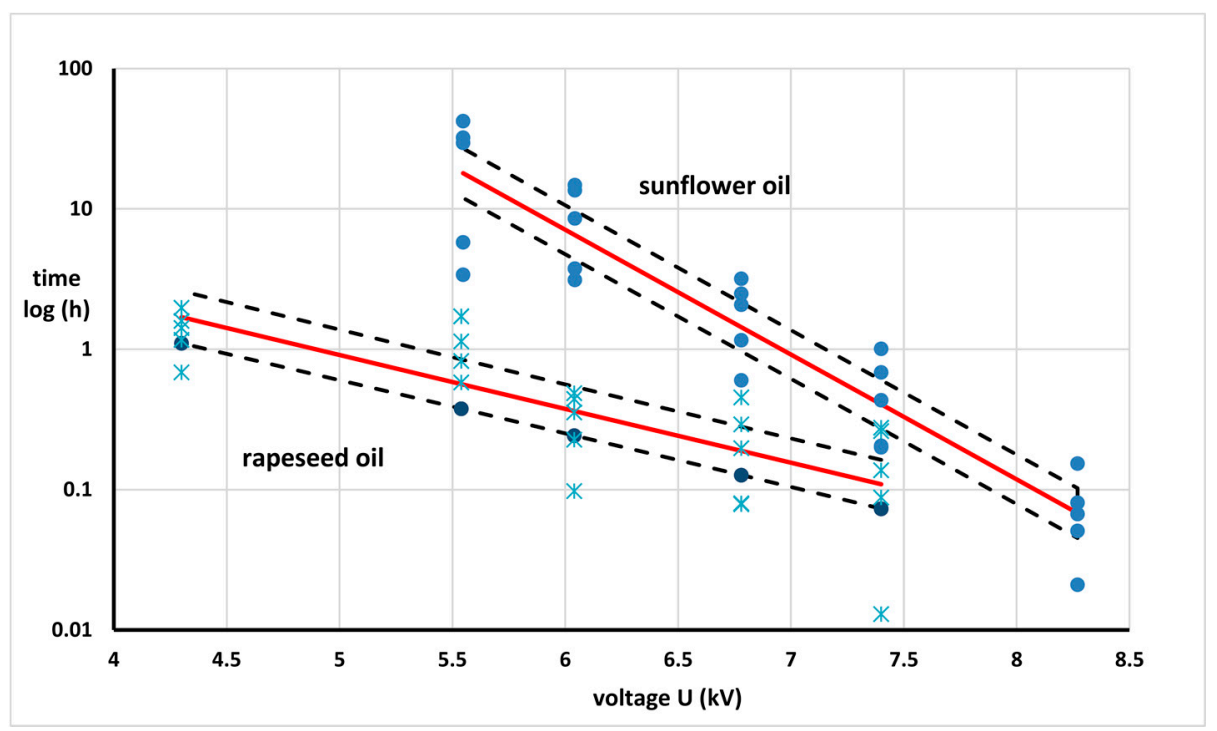

Figure 2. Time to breakdown characteristics for voltage stress exposition. 
The verification of the system's thermal endurance was done by long-term thermal exposure at $140{ }^{\circ} \mathrm{C}$ for $1056 \mathrm{~h}$ and measurement of the dissipation factor and resistivity at regular intervals. Figures 3 and 4 show the values of the dissipation factor for rapeseed and sunflower oil, Figures 5 and 6 show the results of the volume resistivity for both oils.

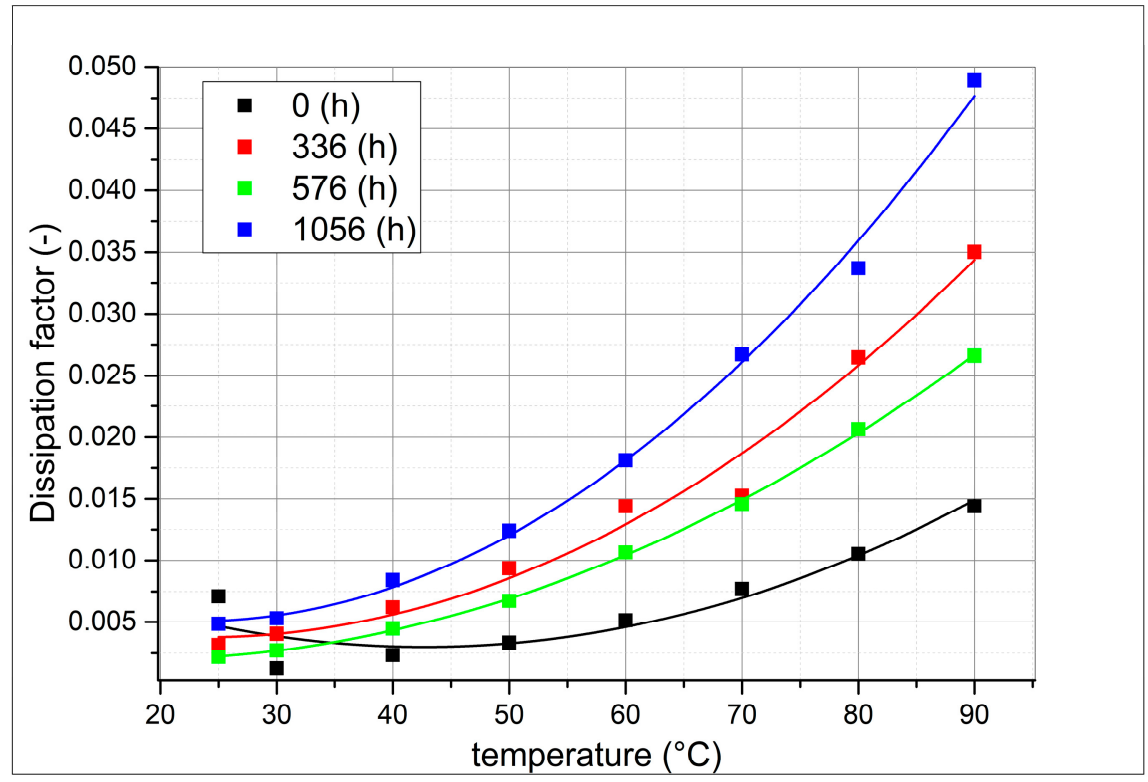

Figure 3. Thermal dependency of the dissipation factor of rapeseed oil at $140{ }^{\circ} \mathrm{C}$ exposure for different exposure times.

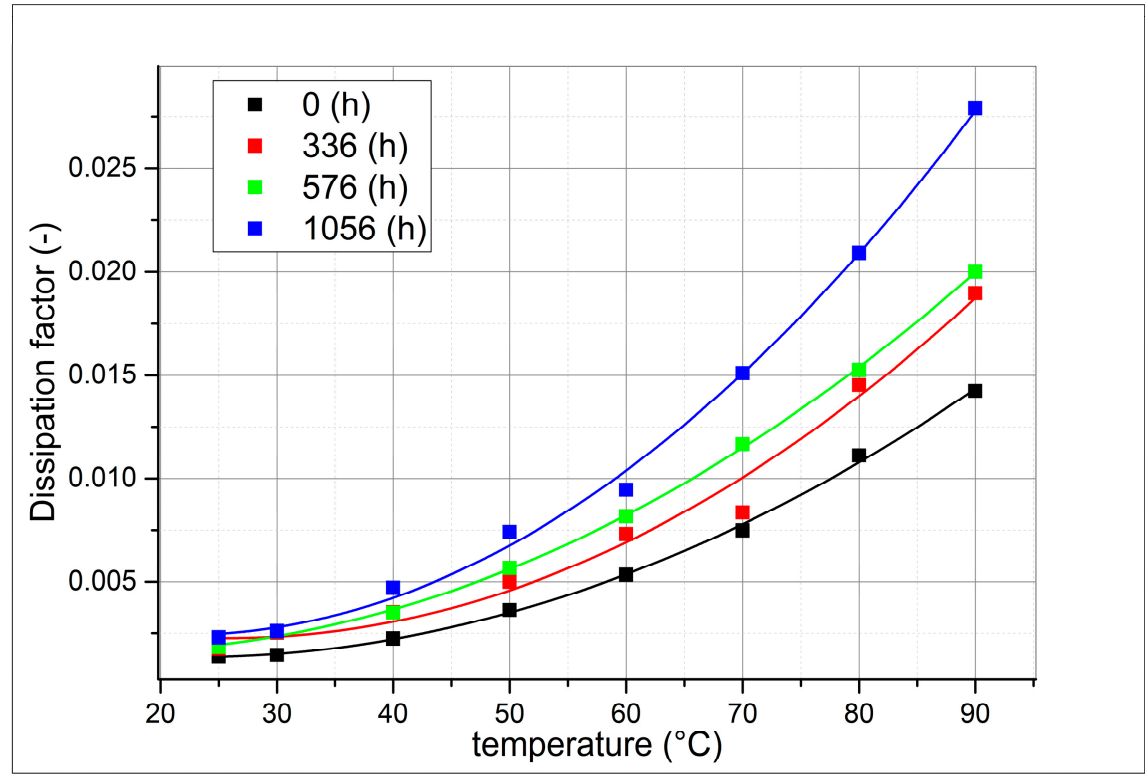

Figure 4. Thermal dependency of the dissipation factor of sunflower oil at $140{ }^{\circ} \mathrm{C}$ exposure for different exposure times.

The obtained thermal dependencies of the dissipation factor clearly states that the initial behavior of non-exposed oils is similar-their values are almost the same up to the value at $90{ }^{\circ} \mathrm{C}$ (a rise of 0.015). After thermal exposure $\left(1056 \mathrm{~h}\right.$ at $\left.140{ }^{\circ} \mathrm{C}\right)$, the sunflower oil exhibits a slightly smaller change $\left(\tan \delta\right.$ at $\left.90{ }^{\circ} \mathrm{C} 0.028\right)$ than rapeseed oil $\left(\tan \delta\right.$ at $\left.90{ }^{\circ} \mathrm{C} 0.05\right)$. 


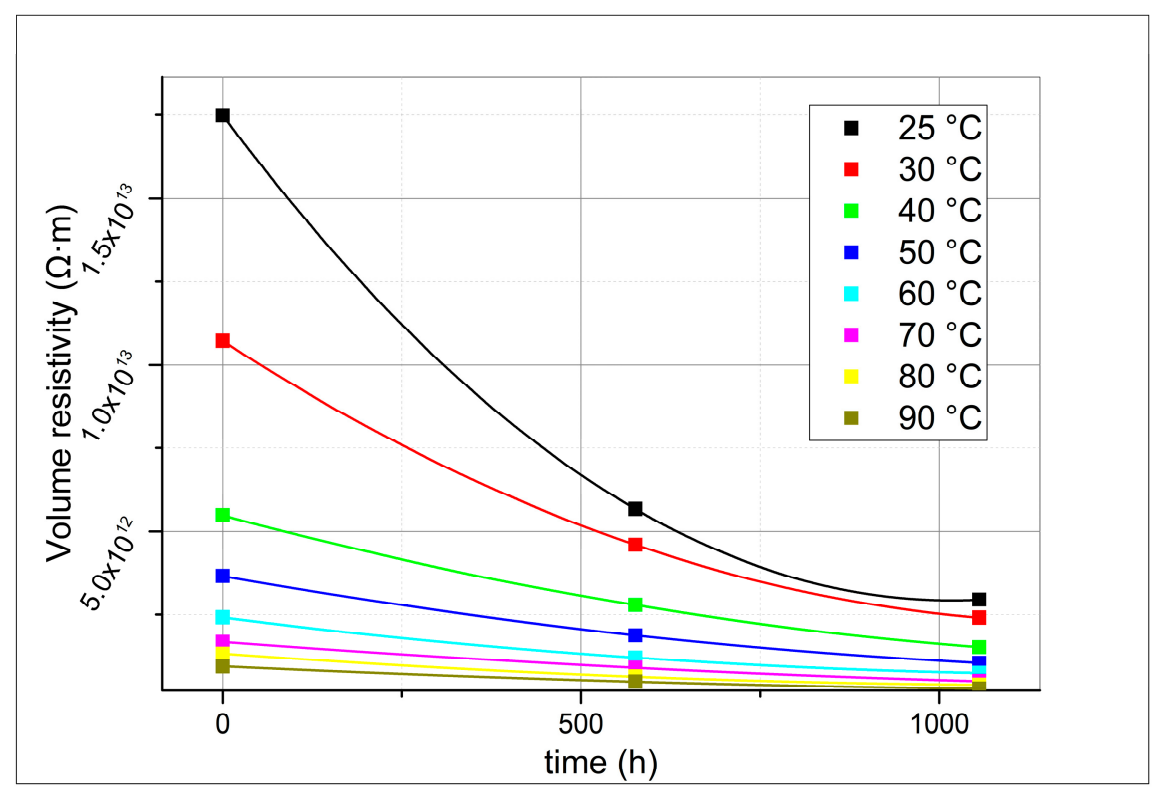

Figure 5. Time dependency of the resistivity of rapeseed oil at $140{ }^{\circ} \mathrm{C}$ exposure.

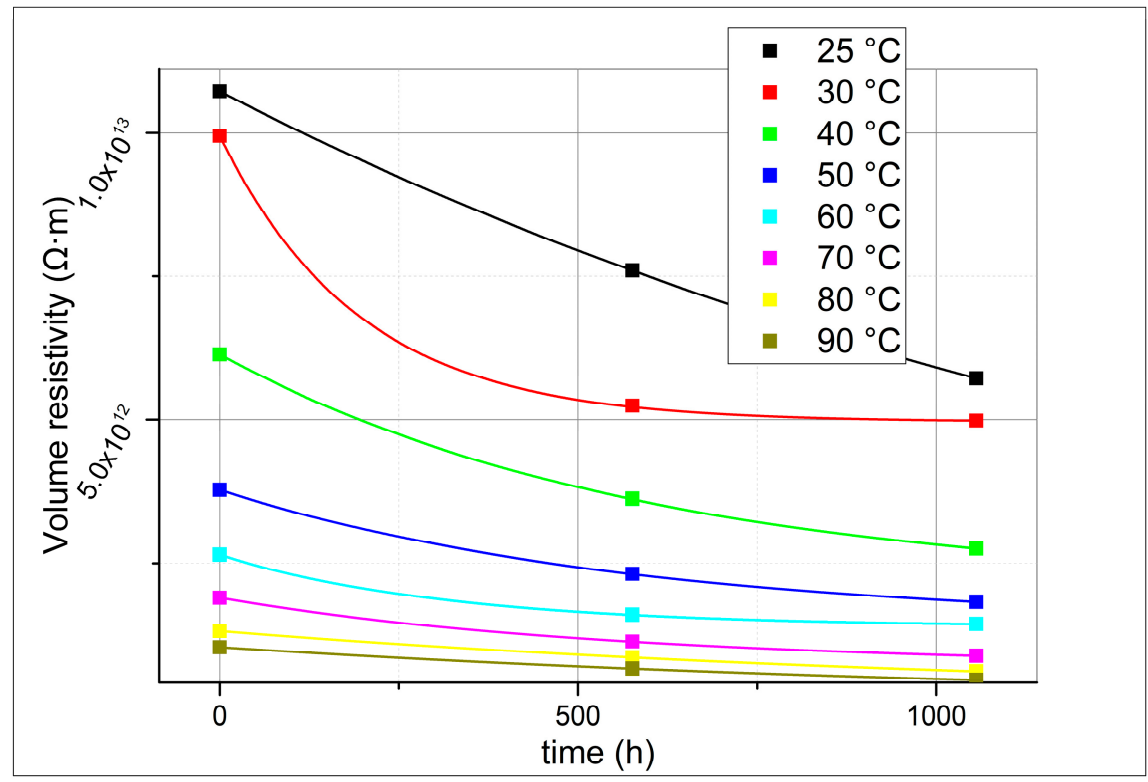

Figure 6. Time dependency of the resistivity of sunflower oil at $140{ }^{\circ} \mathrm{C}$ exposure.

The value of resistivity $\left(25^{\circ} \mathrm{C}\right)$ before thermal exposure at $140{ }^{\circ} \mathrm{C}$ is significantly better for rapeseed oil $\left(1.75 \times 10^{13} \Omega \cdot \mathrm{m}\right)$ than sunflower oil $\left(1.07 \times 10^{13} \Omega \cdot \mathrm{m}\right)$. The situation after thermal exposure $\left(1056 \mathrm{~h}\right.$ at $\left.140{ }^{\circ} \mathrm{C}\right)$ changed a little. The value of resistivity $\left(25^{\circ} \mathrm{C}\right)$ is better for sunflower oil $\left(5.71 \times 10^{12} \Omega \cdot \mathrm{m}\right.$ vs. $9.45 \times 10^{11} \Omega \cdot \mathrm{m}$ for rapeseed oil), as the sunflower oil shows less change over the time of exposure. Finally, we can state that the behavior of both natural ester oils under elevated temperature is similar, with no conclusive differences.

When it comes to the overall classification of oils, the statistically significant difference of slope values under electrical stress comes to play. This, with better value of volume resistivity suggested rapeseed oil as the better of the two in our test. 


\section{Choosing the Rapeseed Base Oil as an Electro-Insulating Liquid}

There are no fully implemented legislative guidelines for the usage of natural esters in transformers so far, but some properties are given in IEC 62770:2013 "Fluids for Electrotechnical Applications-Unused Natural Esters for Transformers and Similar Electrical Equipment" [18]. The values of the individual parameters are mentioned in the middle column of Tables 4 and 5 .

Several commercially available rapeseed oil species have been verified, when searching for a raw material for the new electro-insulating liquid. It is obvious that these oils could not fully comply with the requirements of the Standard IEC 62770 without modifications. These crude oils cannot met the values of some the key parameters e.g., breakdown voltage (BDV), acid number, water content and the dissipation factor $\tan \delta$. Additionally, the values varied for different types and batches of oils. Therefore, it was necessary to adjust the insulating liquid for the desired purpose. In accordance with the present state of knowledge [19], this includes the technology of passing vegetable oil through a column filled with a suitable sorbent and the subsequent appropriate addition of an oxidation inhibitor at the corresponding concentration. This procedure was, of course, initially verified under laboratory conditions, where significant improvements in parameters were demonstrated to the extent that they now met the standard. The modified rapeseed oil passed the test of oxidative stability (TOS) according to method C in standard IEC 61125 [20]. The TOS had to be improved according to IEC-10/939/Q [21] from January 2014 to eliminate the deficiencies of the application of the standard EN 61125 to natural esters. The TOS, which were carried out showed the possibility of the application of modified vegetable oils as an electro-insulating liquid in accordance with the aforementioned standard IEC 62770. The TOS is based on the exposure of an oil sample by oxidation with the presence of copper, and eventually other materials. Changes in the measured parameters of the electro-insulating liquid are monitored before and after exposure. The rapeseed (not erucic) oil with low water content and a low level of volatile substances $0.02 \%$ (compared to other produced oils in food industry quality), produced by Usti Oils s.r.o, was chosen after laboratory tests as a base fluid for further development. Its fatty acid content is visible in Table 3.

Table 3. The components of rapeseed oil—used for the further preparation of an electro-insulating liquid.

\begin{tabular}{ccc}
\hline Component & Unit & Value \\
\hline Fatty acid content lower than C 16 & $\%$ & 0.08 \\
Palmitic acid C 16:0 & $\%$ & 4.1 \\
Stearic acid C 18:0 & $\%$ & 1.6 \\
Oleic acid C 18:1 & $\%$ & 62.7 \\
Linoleic acid C 18:2 & $\%$ & 19.1 \\
Linolenic acid C 18:3 & $\%$ & 9.2 \\
Erucic acid C 22:1 & $\%$ & 0.2 \\
\hline
\end{tabular}

\section{Preparation of the Electro-Insulating Ester Fluid}

Based on the previous laboratory tests, a procedure for the treatment of a larger quantity of vegetable oil by a percolating device was designed (Figure 7a) and subsequently verified. The main scheme of the device is shown in Figure $7 \mathrm{~b}$. The abovementioned rapeseed oil flows from the reservoir (using a $200 \mathrm{~L}$ barrel) at a defined flow of $0.5 \mathrm{~L} / \mathrm{min}$ through a sorbent column. The oil is subsequently returned to the container. The oil is heated to $60{ }^{\circ} \mathrm{C}$ for the viscosity reduction and passes through a composite pulp filter before returning to the tank. Two hundred liters of the oil is treated for approximately $24 \mathrm{~h}$ till the process is finished and requirements of the standard are fulfilled. The oil temperature of $60^{\circ} \mathrm{C}$ has sufficiently adjusted viscosity to allow optimum flow and operation of the device. Figure 7 shows the cylindrical shape of the percolating column. The dimensions are: $\operatorname{Height} 70 \mathrm{~cm}$, the diameter of circular base is $30 \mathrm{~cm}$ and the volume is approximately $50 \mathrm{~L}$. The characteristic parameters of the original and modified rapeseed oil are shown in Table 4. 


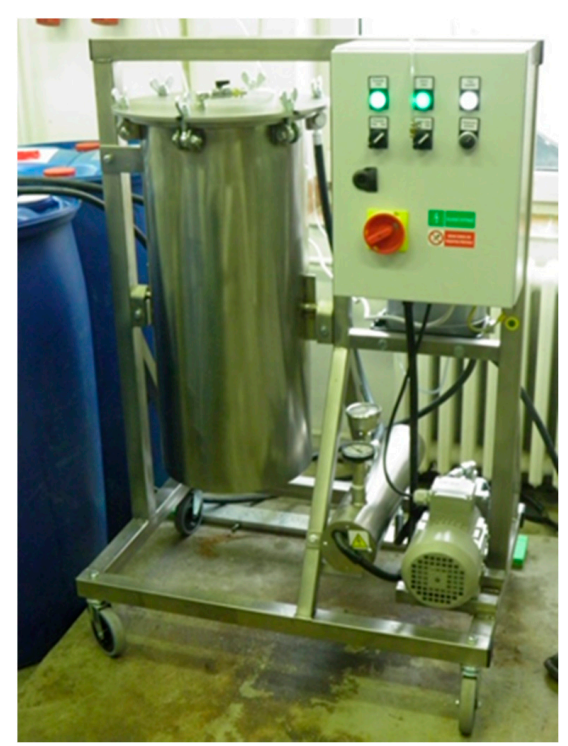

(a)

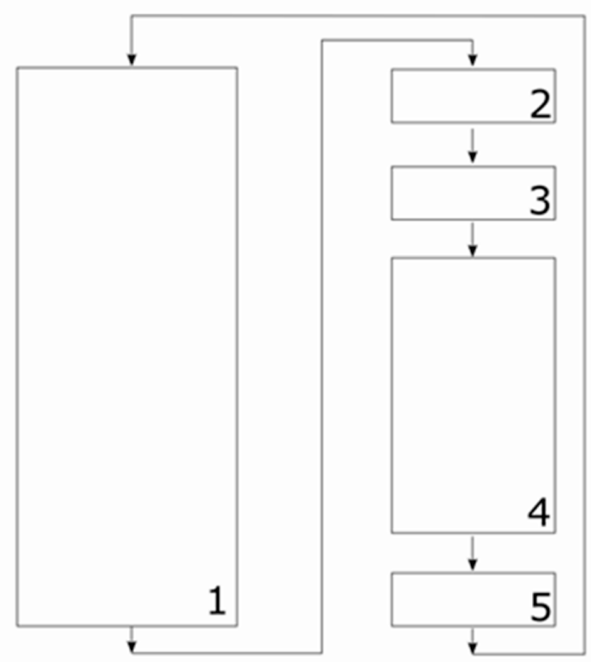

(b)

Figure 7. Percolation device: (a) Device for oil treatment; (b) scheme of rapeseed oil treatment (1—oil container, 2-pump, 3-heating unit, 4-sorbent column, 5-filter).

Table 4. Parameters of original and treated rapeseed oil.

\begin{tabular}{cccc}
\hline Parameter (Unit) & Limit Value from IEC 62770 & Original Oil & Modified Oil \\
\hline Water content $(\mathrm{mg} / \mathrm{kg})$ & Max. 200 & 87.4 & 44.3 \\
Density at $20^{\circ} \mathrm{C}(\mathrm{g} / \mathrm{mL})$ & Max. 1.0 & 0.913 & 0.915 \\
Breakdown voltage $(\mathrm{kV} / 2.5 \mathrm{~mm})$ & Min. 35 & 73.5 & $58.5^{*}$ \\
Dissipation factor at $90^{\circ} \mathrm{C}(-)$ & Max. 0.05 & 0.00477 & 0.00315 \\
Acid number $(\mathrm{mgKOH} / \mathrm{g})$ & Max. 0.06 & 0.091 & 0.02 \\
\hline
\end{tabular}

${ }^{*}$ No degassing.

As it is seen from Table 4, the acid number has been significantly lowered by the oil treatment and meets the criteria of IEC 62770. The value of breakdown voltage was reduced due to the partial foaming of oil during the treatment, but it is still within the limit value.

Another necessary step in the treatment of rapeseed oil is inhibition, i.e., the addition of an oxidation inhibitor. After an experimental verification, the anti-oxidation inhibitor dibutyl-para-cresol (DBPC) [22,23] was added to the obtained rapeseed oil. The results show that pure sunflower oil has slightly better oxidation stability than rapeseed, however after addition of phenolic type of antioxidant the stability of rapeseed oil is higher. The final concentration in the oil was set to $0.5 \mathrm{wt} \%$.

The electro-insulating liquid from the rapeseed oil that has undergone the described modifications was ready for direct use in hermetic distribution transformers and it was protected by utility model number CZ 29982 [24] from 15. 11. 2016 with name ENVITRAFOL. The comparison of its properties with the values given in IEC 62770 is evident in Table 5.

Table 5. Comparison of the characteristic parameters of the ENVITRAFOL with the limit values according to IEC 62770 .

\begin{tabular}{ccc}
\hline Parameter (Unit) & Limit Value from IEC 62770 & ENVITRAFOL \\
\hline & Before Test of Oxidative Stability & \\
\hline Appearance & Clear, free of sediment and suspension & Fulfill \\
Viscosity at $100^{\circ} \mathrm{C}\left(\mathrm{mm}^{2} / \mathrm{s}\right)$ & Max. 15 & 8.26 \\
Viscosity at $40^{\circ} \mathrm{C}\left(\mathrm{mm}^{2} / \mathrm{s}\right)$ & Max. 50 & 35.84 \\
\hline
\end{tabular}


Table 5. Cont.

\begin{tabular}{ccc}
\hline Parameter (Unit) & Limit Value from IEC 62770 & ENVITRAFOL \\
\hline Pour point $\left({ }^{\circ} \mathrm{C}\right)$ & Max. -10 & -24 \\
Water content $(\mathrm{mg} / \mathrm{g})$ & Max. 200 & 45.8 \\
Density at $20^{\circ} \mathrm{C}(\mathrm{g} / \mathrm{mL})$ & 1.0 & 0.915 \\
Breakdown voltage $(\mathrm{kV} / 2.5 \mathrm{~mm})$ & Min. 35 & 60 \\
Dissipation factor at $90^{\circ} \mathrm{C}(-)$ & Max. 0.05 & 0.00358 \\
Acid number $(\mathrm{mgKOH} / \mathrm{g})$ & Max. 0.06 & 0.011 \\
Corrosive sulfur $/ \mathrm{DBDS}$ & absent/below the limit of determination & absent \\
Additives antioxidants $\mathrm{DBCP}(\mathrm{wt} \%)$ & Max. 5 & 0.53 \\
Additives all $(\mathrm{wt} \%)$ & Max. 5 & DBPC only \\
\hline & After Test of Oxidative Stability & \\
\hline Dissipation factor at $90{ }^{\circ} \mathrm{C}(-)$ & Max. 0.5 & 0.02157 \\
Viscosity at $40^{\circ} \mathrm{C}\left(\mathrm{mm}^{2} / \mathrm{s}\right)$ & maximum increase of previous value of 30\% & 35.3 \\
Acid number $(\mathrm{mgKOH} / \mathrm{g})$ & Max. 0.6 & 0.041 \\
\hline
\end{tabular}

As can be seen from Table 5, the new application of natural esters resulting from the treatment of rapeseed oil fully complies with the requirements of IEC 62770. Its properties are comparable to similar products based on natural esters-Midel eN [3] or Envirotemp FR3 [4]. The main advantage is the usage of domestic raw materials with a relatively low price and suitable properties, one of which is biodegradability. This fact means that this oil is applicable in distribution transformers, many of which (in the Czech Republic alone there are more than 125,000 units) are often in exposed areas such as municipalities, and in proximity of drinking water sources or protected natural areas.

\section{Improvements of Electrical Properties}

As can be seen from the above, the new electro-insulating liquid resulting from the natural ester modification has suitable electrical properties. According to the present state of knowledge, the properties of the electro-insulating fluids can be further improved. The authors of numerous papers have dealt with the modification of the properties of mineral oils with nanofillers [25-31]. However, these fluids, as known, cannot meet the OECD-301D requirement for biodegradability. Therefore, the attention is focused on natural based electrical insulating liquids and their possible modification and improvement of some properties using inhibitors, depressants and nanoparticles.

The incorporation of the nanoparticles is proposed in order to improve the electrical properties, especially the key parameters-breakdown voltage and dissipation factor. Nanoparticles incorporated into the fluid system suppress the development of an electrical discharge in the liquid after applying the electrical potential.

The discharge path spreads by the nanoparticles, which leads to a slowing of its development and thus to an increase of the value of the flashover/breakdown voltage as well as to an improvement of the other electrical properties while preserving the overall physical and chemical parameters of the oil. Therefore the attention is focused on the modification of the natural ester by nanoparticles in this matter. The access is described in the following.

Based on the previous experience, and taking into consideration the conclusions of the above cited articles concerning mineral oils, these were the selected nanoparticles for the verification of the possibility of modifying the electrical properties of natural esters: $\mathrm{TiO}_{2}, \mathrm{Al}_{2} \mathrm{O}_{3}, \mathrm{SiO}_{2}, \mathrm{ZnO}$. Table 6 gives an overview of the selected nanoparticles.

Table 6. Overview of selected nanoparticles to modify new oil properties.

\begin{tabular}{ccccc}
\hline Nanofiller Oxide & Purity (\%) & Primary Particle Size (nm) & Variation & Surface Treatment \\
\hline $\mathrm{TiO}_{2}$ & $\begin{array}{c}>96 \mathrm{TiO}_{2} \\
<4 \mathrm{SiO}_{2}\end{array}$ & 20 & $\begin{array}{c}\text { hydrophilic } \\
\text { UV resistive }\end{array}$ & $\mathrm{SiO}_{2}$ \\
\hline $\mathrm{TiO}_{2}$ & $99+$ & 20 & - & - \\
\hline $\mathrm{Al}_{2} \mathrm{O}_{3}-\gamma$ & 99.97 & $20-30$ & - & - \\
\hline
\end{tabular}


Table 6. Cont.

\begin{tabular}{ccccc}
\hline Nanofiller Oxide & Purity (\%) & Primary Particle Size (nm) & Variation & Surface Treatment \\
\hline $\mathrm{Al}_{2} \mathrm{O}_{3}-\gamma$ & 99.99 & 10 & - & - \\
\hline $\mathrm{SiO}_{2}$ & $\begin{array}{c}\geq 98 \mathrm{SiO}_{2} \\
\leq 2 \\
\text { (3-Aminopropyl) } \\
\text { triethoxysilan }\end{array}$ & 20 & $\begin{array}{c}\text { hydrophilic } \\
\text { lipophilic }\end{array}$ & $\begin{array}{c}\text { (3-Aminopropyl) } \\
\text { triethoxysilan }\end{array}$ \\
\hline $\mathrm{SiO}_{2}$ & $99+$ & 20 & hydrophilic & - \\
\hline $\mathrm{ZnO}$ & $\begin{array}{c}\geq 98 \mathrm{ZnO} \\
\leq 2-\text { Aminopropyl) } \\
\text { triethoxysilan }\end{array}$ & 30 & $\begin{array}{c}\text { hydrophilic } \\
\text { lipophilic }\end{array}$ & $\begin{array}{c}\text { (3-Aminopropyl) } \\
\text { triethoxysilan }\end{array}$ \\
\hline $\mathrm{ZnO}$ & $99+$ & 20 & - & - \\
\hline $\mathrm{ZnO}$ & $99+$ & 30 & - & - \\
\hline
\end{tabular}

The selection was carried out in several respects. The first is a type of nanoparticle. The second is material purity and particle size in $\mathrm{nm}$. The third is surface treatment (ST), since it is known to play a significant role [29], particularly in terms of the incorporation of particles into the fluid system.

\section{Incorporation of Individual Types of Nanoparticles}

The first test selected for verification of prepared ENVITRAFOL nanofluids was the breakdown voltage test. This test was performed according to IEC 60156:1995 [32] in a standardized electrode system and ambient temperature, $2.5 \mathrm{~mm}$ distance, $440 \mathrm{~mL}$ of nanofluid, six breakdowns with five-minute pauses between breakdowns.

The weight content of nanofillers in the base oil was chosen from zero (pure ENVITRAFOL) and then fractions of a weight percent- $0.05,0.1,0.2,0.25,0.3,0.4,0.5$ and $1 \mathrm{wt} \%$. All samples were prepared using the same procedure. The obtained results of maximal breakdown voltage are shown in Table 7.

Table 7. Maximal breakdown voltages of the nanofluids.

\begin{tabular}{cccccc}
\hline$\#$ & Nanofiller & Surface Treatment & $\begin{array}{c}\text { Primary } \\
\text { Particle Size } \\
\mathbf{( n m )}\end{array}$ & $\begin{array}{c}\text { Max. Breakdown } \\
\text { Voltage BDV } \\
\mathbf{( k V / 2 . 5} \mathbf{~ m m})\end{array}$ & $\begin{array}{c}\text { Weight Content } \\
\text { at max. BDV } \\
\mathbf{( \% )}\end{array}$ \\
\hline 1 & $\mathrm{TiO}_{2}$ & $\mathrm{SiO}_{2}$ & 20 & 80.1 & 0.25 \\
2 & $\mathrm{TiO}_{2}$ & - & 20 & 75.6 & 0.25 \\
3 & $\mathrm{Al}_{2} \mathrm{O}_{3}-\gamma$ & - & 10 & 74.3 & 0.2 \\
4 & $\mathrm{Al}_{2} \mathrm{O}_{3}-\gamma$ & - & $20-30$ & 73.2 & 0.2 \\
5 & $\mathrm{ZnO}$ & - & 20 & 72 & 0.3 \\
6 & $\mathrm{ZnO}$ & (3-Aminopropyl) triethoxysilan & 30 & 70.8 & 0.3 \\
7 & $\mathrm{ZnO}$ & - & 30 & 68.5 & 0.2 \\
8 & $\mathrm{SiO}_{2}$ & (3-Aminopropyl) triethoxysilan & 20 & 65.9 & 0.2 \\
9 & $\mathrm{SiO}_{2}$ & - & 30 & 64.5 & 0.2 \\
\hline
\end{tabular}

The selected nanoparticles and ester oil samples were first dried at $110^{\circ} \mathrm{C}$ for $18 \mathrm{~h}$. During cooling the given amount of nanofillers was mixed into the oil. The resulting fluid system was then mixed with a double helix stirrer for one hour and subsequently a $200 \mathrm{~W}$ ultrasonic mixer was used for two hours using a frequency of $40 \mathrm{kHz}$. After this process, the sample of the fluid system was ready for testing. All nanoparticles listed in Table 6 have been tested. The obtained results are shown in Table 8 and Figure 8.

\section{Results and Discussion}

From the results (Table 7 and Figure 8), the following conclusions can be drawn: titanium dioxide with a silica surface treatment $\left(\mathrm{SFT} \mathrm{TiO}_{2}\right)$ has the maximal positive effect on $\mathrm{BDV}(80.1 \mathrm{kV} / 2.5 \mathrm{~mm}$ by $0.25 \mathrm{wt} \%$ vs. $60 \mathrm{kV} / 2.5 \mathrm{~mm}$ for the pure oil) from tested samples. As expected, the influence of surface treatment of the nanoparticles plays significant role as seen from results of BDV of nanofluids with $\mathrm{TiO}_{2} 75.6 \mathrm{kV} / 2.5 \mathrm{~mm}$. As seen from results with $\mathrm{Al}_{2} \mathrm{O}_{3}-\gamma$ : the values of $\mathrm{BDV}$ with the nanoparticles 
with a size of $10-20 \mathrm{~nm}$ are nearly the same as for $10 \mathrm{~nm}, 74.3 \mathrm{vs} .73 .2 \mathrm{kV} / 2.5 \mathrm{~mm}$. Thus, in this case, the particle size does not have an impact on BDV. The maximal BDV is in this case for $0.2 \%$ a mass of $\mathrm{Al}_{2} \mathrm{O}_{3}-\gamma$, but is still nearly $6 \mathrm{kV}$ lower than for those with silica-coated $\mathrm{TiO}_{2}$. BDV of nanofluids with $\mathrm{ZnO}$ is $72(20 \mathrm{~nm})$ respectively $70.5 \mathrm{kV} / 2.5 \mathrm{~mm}$ for SFT $\mathrm{ZnO}(30 \mathrm{~nm})$ and 68.5 for $\mathrm{ZnO}(30 \mathrm{~nm})$. In this case, nanofluids have the highest BDV with $20 \mathrm{~nm}$ nanoparticles, the surface treatment of the particles is beneficial in the case of $30 \mathrm{~nm}$ particles. The lowest BDV has nanofluid with $\mathrm{SiO}_{2}$ nanoparticles. Here, the influence of surface treatment (3-aminopropyl) triethoxysilane is low $(65.9$ vs. $64.5 \mathrm{kV} / 2.5 \mathrm{~mm})$. However the all samples proved increasing of BDV compared to pure ester oil at around $0.25 \mathrm{wt} \%$ of nanofiller.

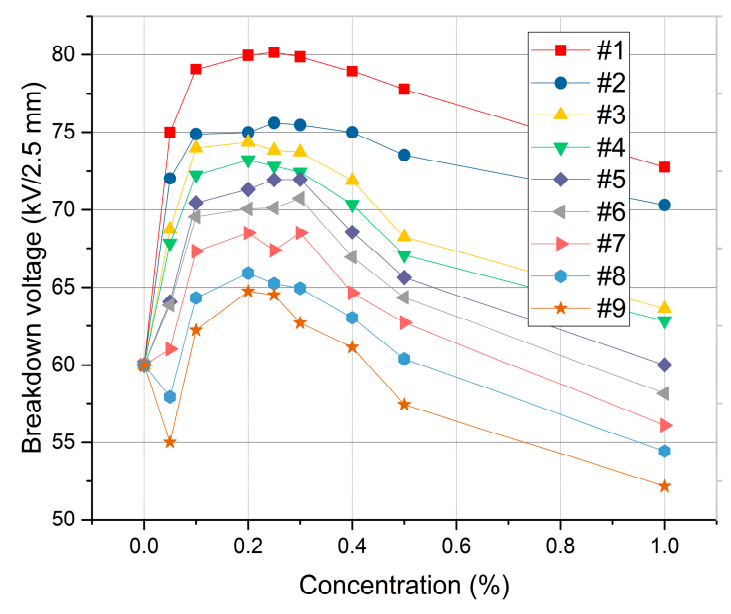

Figure 8. Breakdown voltages of nanofluids.

The increase of the BDV and volume resistivity by addition of nanofiller in concentration of $0.25 \mathrm{wt} \%$ can be explained by the creation of surface charges on the particles. These charges act against the outer electric field in the fluid, and thus the local field is lowered and electron cascades from the electrode are shifted toward a higher voltage. This phenomenon appears as an improvement of the listed properties. We can observe similar phenomena as e.g., in case of the electrical tree growing in material with and without nanoparticles. Reference [33] claimed that nanoparticles distributed in polymers could create a "fence effect", and make the growing path of the electrical tree twist and turn like a " $Z$ " shape, so that more energy would be consumed. Similar phenomena can be expected in liquid dielectric, but due to the higher mobility of the molecules there is lower effect of the carbonization of the channel and therefore the increase of the high field at the end of the channel/avalanche does not occur. Still, due to the presence of nanoparticles, the more complicated path of the pre-breakdown channel consumes more energy and leads to the improvement of the measured BDV.

The abovementioned results tell us that the addition of nanoparticles significantly improved the BDV, which was already confirmed earlier for mineral oils [34]. Generally, the improvement of breakdown voltage of nanofluids may be caused by increased shallow trap density in the liquid. These traps could convert fast electrons to slow electrons by the trapping and de-trapping processes [35]. However, other factors are also important. The hydrophilicity of nanoparticles plays a great role in comparison with the effect of the surface treatment itself [36], because the hydrophilic surface can bind the water absorbed in the insulation liquid. Nevertheless, from the results it is also visible that the origin and usability of surfactant is also important [37]. The next one is the filler concentration. Figure 8 further shows a tendency of the BDV with the oil filling concentration. The BDV increases to a concentration of approximately $0.2 \mathrm{wt} \%$, the maximum is in the range of $0.2-0.3 \mathrm{wt} \%$. Higher concentrations of nanoparticles have a negative effect on the BDV. A higher concentration may cause an overlap of the interaction layers on the particle surface. Taking into account the fact that the particle 
is usually covered by $5-10 \mathrm{H}_{2} \mathrm{O}$ molecules tightly bound to its surface and that they may absorb additional water from oil, then the conductive paths may be created [38]. However, there are many additional variables which may also contribute in a minor effect to changes of breakdown voltage behavior (size, specific surface area, morphology, viscosity, moisture, etc.) [39]. The abovementioned investigations confirm that these hypotheses which were obtained for mineral oils are valid for natural ester oils as well.

The behavior of the modified oil samples is also interesting to observe in terms of statistical parameters, which are detailed in Table 8 . The analysis of the basic statistical values of the BDV of the oils samples provides the titanium dioxide with silica surface treatment at $0.25 \mathrm{wt} \%$ at $25^{\circ} \mathrm{C}$ has a minimal variation coefficient.

Table 8. Breakdown voltages (BDV) of the nanofluid samples.

\begin{tabular}{cccccccccc}
\hline$\#$ & $\mathbf{1}$ & $\mathbf{2}$ & $\mathbf{3}$ & $\mathbf{4}$ & $\mathbf{5}$ & $\mathbf{6}$ & $\mathbf{7}$ & $\mathbf{8}$ & $\mathbf{9}$ \\
\hline $\operatorname{Max}(\mathrm{kV})$ & 82.96 & 78.52 & 77.21 & 75.69 & 74.23 & 73.35 & 70.88 & 70.86 & 68.31 \\
$\operatorname{Min}(\mathrm{kV})$ & 77.61 & 73.11 & 69.46 & 69.33 & 69.15 & 66.06 & 61.96 & 60.16 & 59.52 \\
$\mathrm{X} 0.25(\mathrm{kV})$ & 79.12 & 73.83 & 73.03 & 71.66 & 70.18 & 67.56 & 66.15 & 62.42 & 63.36 \\
X0.75 $(\mathrm{kV})$ & 81.03 & 76.68 & 76.31 & 75.24 & 73.12 & 72.31 & 69.62 & 68.64 & 66.62 \\
$\sigma^{2}\left(\mathrm{kV}^{2}\right)$-dispersion & 3.24 & 3.81 & 7.53 & 5.59 & 3.70 & 7.94 & 9.78 & 15.63 & 9.04 \\
$\mathrm{v}(\%)$ - variation coefficient & 2.25 & 2.58 & 3.72 & 3.25 & 2.67 & 4.02 & 4.64 & 6.06 & 4.66 \\
\hline
\end{tabular}

The sample with the addition of surface treated with $\mathrm{TiO}_{2}$ was further studied in order to characterize the basic electrical characteristics: Volume resistivity $\varrho_{\mathrm{v}}$, minute polarization index PI and dissipation factor tan $\delta$. The Tettex 2830/2831 Solid and Liquid Dielectric Analyzer with Tettex 2903 liquid dielectric capacitor (distance $2 \mathrm{~mm}$, oil volume $40 \mathrm{~mL}$ ) was used for these measurements.

In Figure 9, the temperature dependence of volume resistivity is presented. Volume resistivity $\left(25^{\circ} \mathrm{C}\right.$ ) of nanofluids with surface treated with $\mathrm{TiO}_{2}$ particles rise from $1.09 \times 10^{11}$ to $7.42 \times 10^{11} \Omega \cdot \mathrm{m}$ for $0.25 \mathrm{wt} \%$. The measured increase of the volume resistivity by addition of nanofillers is in agreement with the measured BDV increase. The particles create a charge on its surface (Stern layer [40]) acting against the main electric filed. The probability of electron scattering increases. This leads to a reduction of the impact energy of electrons and thus prevents the oil from ionizing [37]. The re-drop of the resistivity with a higher concentration than $0.25 \mathrm{wt} \%$ can be explained by an increase of free charge carriers caused by s higher concertation of the nanofillers and the activation of the interaction between particles and their interface layers. The column diagram in Figure 10 shows the dependence of the volume resistivity of the oil at $90{ }^{\circ} \mathrm{C}$ on the concentration of the surface treated $\mathrm{TiO}_{2}$ with maximum at concentration of $0.25 \mathrm{wt} \%$.

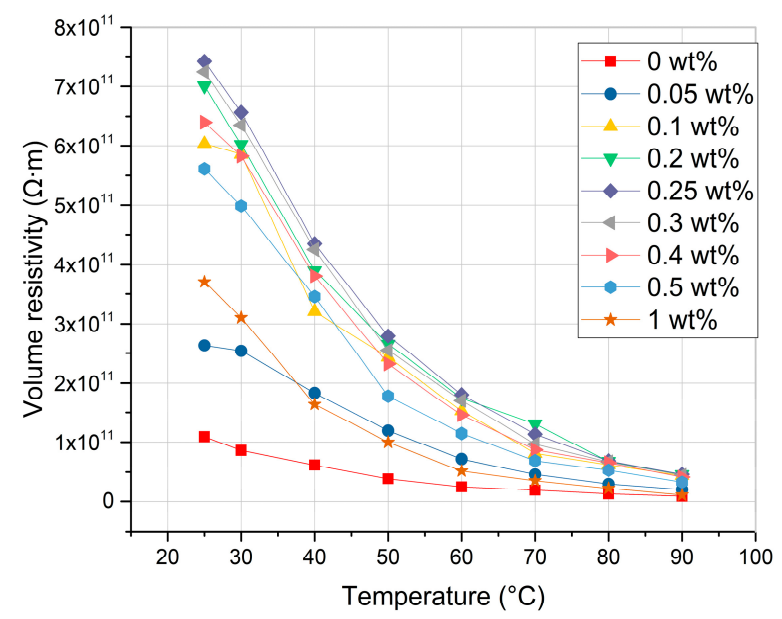

Figure 9. Temperature dependence of the volume resistivity of nanofluids with $\mathrm{ST}^{\mathrm{TiO}_{2}}$. 


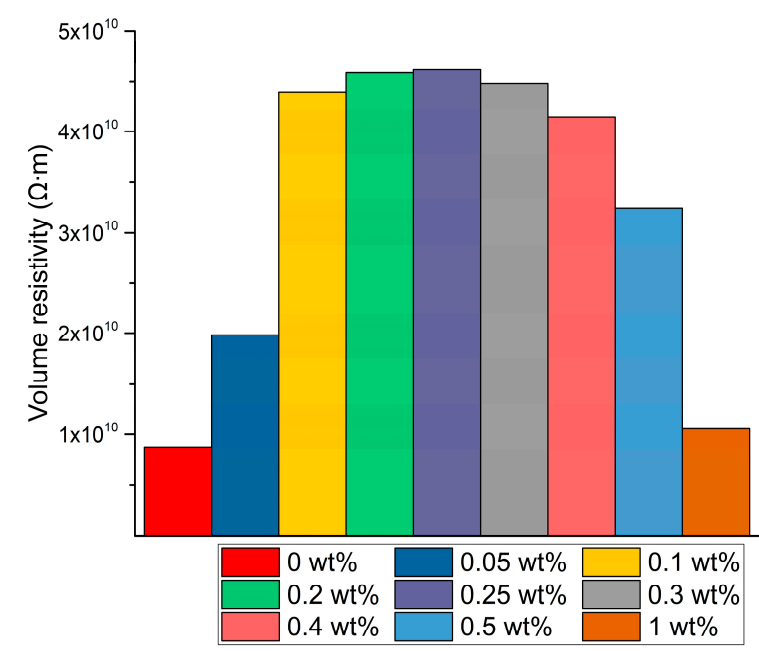

Figure 10. Dependence of the volume resistivity of nanofluids with $\mathrm{ST} \mathrm{TiO}_{2}$ on nanoparticle concentration, $90^{\circ} \mathrm{C}$.

The minute polarization index has the same trend since the same polarization current $\mathrm{I}_{60 \mathrm{~s}}$ is used for calculation. The application of the $\mathrm{ST}_{\mathrm{TiO}_{2}}$ yielded an increase in the minute polarization index from 1.12 to 1.67. This fact corresponds with the phenomena of particle surface charge which is described above.

The dissipation factor tan $\delta$ was improved as well by the addition of $\mathrm{ST}_{\mathrm{TiO}_{2}}$ (from 0.00148 to $0.00045)$, measured at $25^{\circ} \mathrm{C}$. The temperature dependence of the dissipation factor is presented in Figure 11. It can be seen that the minimum is at the concentration of $0.25 \mathrm{wt} \%$. The dissipation factor increases for higher concentrations than $0.25 \mathrm{wt} \%$. The column diagram in Figure 12 captures the dependence of the dissipation factor on the nanoparticle concentration at $25^{\circ} \mathrm{C}$.

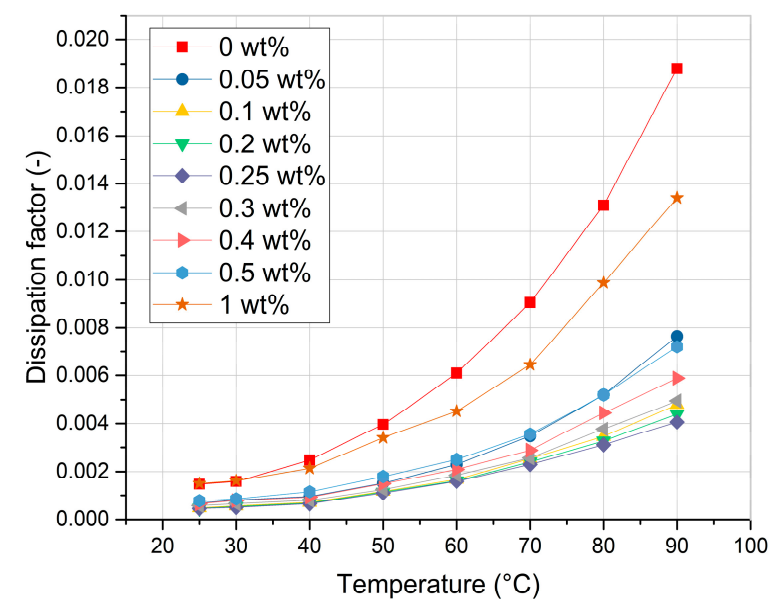

Figure 11. Temperature dependence of the dissipation factor of nanofluids with $\mathrm{ST}_{\mathrm{TiO}_{2}}$. 


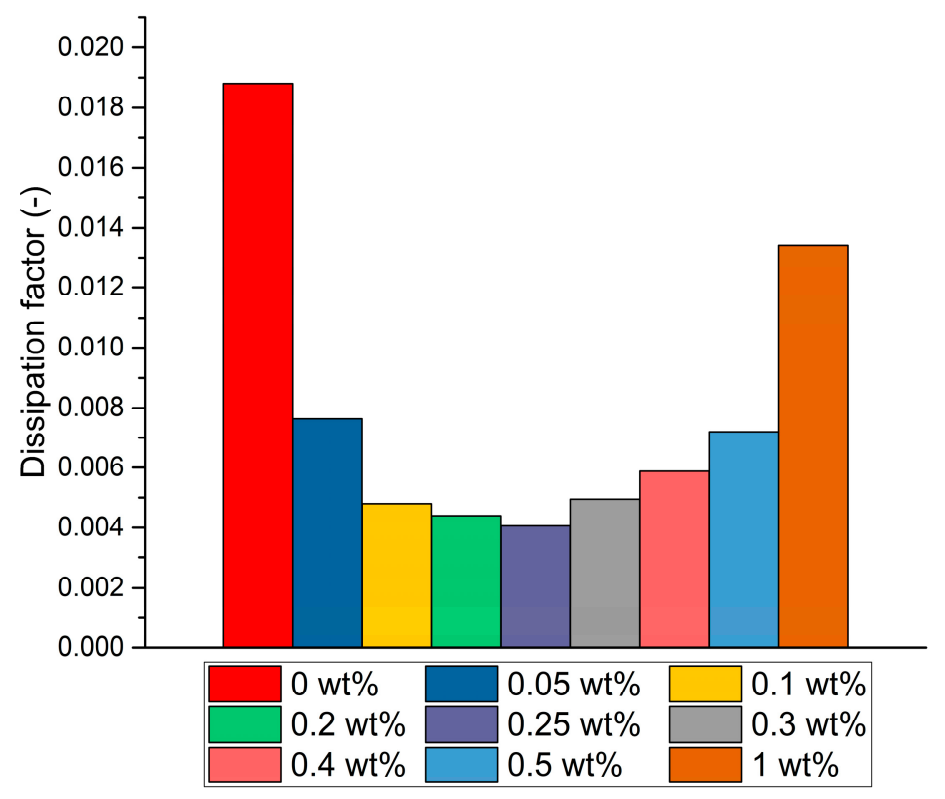

Figure 12. Content dependence of the dissipation factor of nanofluids with $\mathrm{ST}^{\mathrm{TiO}_{2}, 25}{ }^{\circ} \mathrm{C}$.

As was mentioned above, the application of natural esters in transformers has several pros and cons $[2,6,12]$. The main advantage is their environmental compatibility, biodegradability and high flash $\left(<200^{\circ} \mathrm{C}\right)$ and fire points $\left(<300^{\circ} \mathrm{C}\right)$. For this reason, these natural ester oils can be classified as a "substance nonhazardous to waters" [41]. From the experiments which were carried out, it can be said that the presence of oxygen greatly affects the oxidative stability. For this reason, it is necessary to avoid the access of air to the transformer tank. This fact leads to the recommendation for application of natural ester oils in hermetically sealed transformers, in our case distribution transformers. The next discussed point is the higher viscosity of natural ester oil in comparison with mineral oil. This may cause an increase of temperature in the whole transformer [42]. This is solved by changing the cooling circuit design, which would lead to a reduction of the oil temperature [43]. On the other hand, it results in an increase of the power consumption of the oil pumps because these pumps must be able to pump a medium of higher viscosity [44]. The other thing which has to be changed is impregnation process of cellulose pressboard. This is also associated with a higher viscosity of natural ester oils. Increasing the impregnation temperature and prolonging the standing time will ensure satisfactory impregnation [45]. From these overviews is visible that it is difficult to apply natural esters without further transformer adjustments. However, if all these features are already included in the machine design itself, the potential of natural esters can be fully utilized e.g., in areas of increased environmental protection [6], such as shopping centers, protected natural areas, natural parks, proximity to water sources, etc. The next possibility for using a natural ester is retrofilling mineral oil transformers. It may reduce the moister content absorbed in cellulose-based pressboard due to moister migration and subsequent hydrolysis [13]. It leads to a slower aging process of cellulose pressboard [46].

\section{Conclusions}

The main aim of this paper was to describe the step-by-step development of an alternative electro-insulating liquid based on natural esters grown in Central Europe. The oxidative stability and long-term AC voltage exposure were the criteria parameters for rapeseed oil selection in comparison with sunflower oil which was also pre-tested. Rapeseed oil contains a high number of saturated fatty acids which make the oil oxidation stable and thus usable in long-term applications.

The original rapeseed oil had to be modified to meet the standards given by IEC 62770:2013. The percolation device was constructed. The acid number was significantly lowered by the oil treatment 
and acid number met the criteria given by IEC 62770:2013. The treated oil was also inhibited by the addition of DBPC in a concentration of $0.5 \mathrm{wt} \%$. The modified rapeseed oil is ready for direct use in hermetized distribution transformers and it is protected by utility model number CZ 29982 with name ENVITRAFOL.

ENVITRAFOL was then modified with different kinds of nanoparticles to achieve even better parameters, according to the modern development trend. The silica-coated titanium dioxide $\left(\mathrm{ST}^{\mathrm{TiO}} 2\right)$ particles in a verified content of $0.25 \mathrm{wt} \%$ uniformly dispersed in ENVITRAFOL resulting in the largest improvement of several properties. The most significant change was observed in BDV behavior. The average value of BDV was increased from 60 to $80.15 \mathrm{kV} / 2.5 \mathrm{~mm}$. However, other parameters were also improved. The dissipation factor decreased by an order, volume resistivity raised from $1.09 \times 10^{11}$ to $7.42 \times 10^{11}, 25^{\circ} \mathrm{C}$ and the polarization index was raised from 1.12 to 1.67 .

The resulting ENVITRAFOL with $\mathrm{ST} \mathrm{TiO}_{2}$ is proposed to be a liquid component of electrical isolation systems for electric equipment, e.g., distribution transformers (voltage levels tens of $\mathrm{kV}$, rated power tens of kVA to tens of MVA) operated mainly in areas requiring increased environmental protection (municipalities, protected natural areas, natural parks, proximity to water sources, etc.) where any possible contamination would be an environmental issue. The use of this biodegradable electro-insulating nanofluid further supports the fact that its production is not technologically demanding and as an advantage it uses an easily accessible domestic renewable source which makes it economically beneficial compared to synthetic fluids.

Acknowledgments: This work is supported by the Ministry of Education, Youth and Sports of the Czech Republic under the RICE-New Technologies and Concepts for Smart Industrial Systems, project No. LO1607 and by the Student Grant Agency of the West Bohemia University in Pilsen, grant No. SGS-2018-016 Diagnostics and materials in electrotechnics.

Author Contributions: Vaclav Mentlik conceived and designed the experiments; Vaclav Mentlik, Pavel Trnka, Jaroslav Hornak, Pavel Totzauer performed the experiments, analyzed the data and wrote the paper. Jiri Ulrych a Jan Kubes performed some measurements.

Conflicts of Interest: The authors declare no conflict of interest.

\section{References}

1. OECD. Ready Biodegradability; Organisation for Economic Co-operation and Development: Paris, France, 1992.

2. Rafiq, M.; Lv, Y.Z.; Zhou, Y.; Ma, K.B.; Wang, W.; Li, C.R.; Wang, Q. Use of vegetable oils as transformer oils-A review. Renew. Sust. Energy Rev. 2015, 52, 308-324. [CrossRef]

3. MIDEL I Natural Ester Fluid/Vegetable Oil. Available online: www.midel.com/productsmidel/midel-en (accessed on 4 January 2018).

4. FR3 Fluid I Dielectric Ester Fluid I Mineral Oil Replacement I Cargill. Available online: www.cargill.com/ bioindustrial/envirotemp/fr3 (accessed on 4 January 2018).

5. Perrier, C.; Beroual, A. Experimental investigations on mineral and ester oils for power transformers. In Proceedings of the 2008 IEEE International Symposium on Electrical Insulation, Vancouver, BC, Canada, 9-12 June 2008; pp. 178-181. [CrossRef]

6. Mehta, D.R.; Kundu, P.; Chowdhury, A.; Lakhiani, V.K.; Jhala, A.S. A review on critical evaluation of natural ester vis-a-vis mineral oil insulating liquid for use in transformers: Part 1. IEEE Trans. Dielectr. Electr. Insul. 2016, 23, 873-880. [CrossRef]

7. Guo, P.; Liao, R.; Hao, J.; Ma, Z.; Yang, L. Research on the temperature dielectric spectrum of vegetable oil, mineral oil and their relevant oil-impregnated papers. In Proceedings of the 2012 International Conference on High Voltage Engineering and Application, Shanghai, China, 17-20 September 2012; pp. 562-565. [CrossRef]

8. Bakrutheem, M.; Iruthayarajan, W.M.; Kumar, S.S. Investigation on the properties of natural esters blended with mineral oil and pyrolysis oil as liquid insulation for high voltage transformers. In Intelligent and Efficient Electrical Systems; Bhuvaneswari, M.C., Saxena, J., Eds.; Springer: Singapore, 2018; pp. 187-196. ISBN 978-981-10-4851-7.

9. Choi, S.; Huh, C. The lightning impulse properties and breakdown voltage of natural ester fluids near the pour point. J. Electr. Eng. Technol. 2013, 8, 524-529. [CrossRef] 
10. Rapp, K.J.; Corkran, J.; McShane, C.P.; Prevost, T.A. Lightning impulse testing of natural ester fluid gaps and insulation interfaces. IEEE Trans. Dielectr. Electr. Insul. 2009, 16, 1595-1603. [CrossRef]

11. Martins, M.A.G. Vegetable oils, an alternative to mineral oil for power transformers- experimental study of paper aging in vegetable oil versus mineral oil. IEEE Electr. Insul. Mag. 2010, 26, 7-13. [CrossRef]

12. Bertrand, Y.; Lauzevis, P. Development of a low viscosity insulating liquid based on natural esters for distribution transformers. In Proceedings of the 22nd International Conference and Exhibition on Electricity Distribution, Stockholm, Sweden, 10-13 June 2013. [CrossRef]

13. Moore, S.; Rapp, K.; Baldyga, R. Transformer insulation dry out as a result of retrofilling with natural ester fluid. In Proceedings of the 2012 IEEE PES Transmission and Distribution Conference and Exposition (T\&D), Orlando, FL, USA, 7-10 May 2012. [CrossRef]

14. Jahreis, G.; Schäfer, U. Rapeseed (Brassica napus) Oil and its Benefits for Human Health. In Nuts and Seeds in Health and Disease Prevention; Preedy, V., Watson, R.R., Patel, V., Eds.; Academic Press: Burlington, MA, USA, 2011; pp. 967-974. ISBN 978-0-12-375688-6.

15. Pal, D. Sunflower (Helianthus annuus L.) Seeds in Health and Nutrition. In Nuts and Seeds in Health and Disease Prevention; Preedy, V., Watson, R.R., Patel, V., Eds.; Academic Press: Burlington, MA, USA, 2011; pp. $967-974$. ISBN 978-0-12-375688-6.

16. CIGRE. Experiences in Service with New Insulating Liquids; CIGRE Brochure N ${ }^{\circ}$ 436; CIGRE: Paris, France, 2010.

17. Julliard, Y.; Badent, R.; Schwab, A.J. Influence of water content on breakdown behavior of transformer oil. In Proceedings of the Conference on Electrical Insulation and Dielectric Phenomena, Kitchener, ON, Canada, 14-17 October 2001; pp. 544-547. [CrossRef]

18. IEC. Fluids for Electrotechnical Applications-Unused Natural Esters for Transformers and Similar Electrical Equipment; IEC 62770:2013; International Electrotechnical Commission: Geneva, Switzerland, 2013.

19. Wilhelm, H.M.; Stocco, G.B.; Batista, S.G. Reclaiming of in-service natural ester-based insulating fluids. IEEE Trans. Dielectr. Electr. Insul. 2013, 20, 128-134. [CrossRef]

20. IEC. Unused Hydrocarbon Based Isulating Liquids-Test Methods for Evaluating the Oxidation Stability; IEC 61125:1992; International Electrotechnical Commission: Geneva, Switzerland, 1992.

21. IEC. Proposed Revision of IEC 61125 Ed.1, Unused Hydrocarbon Based Insulating Liquids-Test Methods for Evaluating the Oxidation Stability; IEC-10/939/Q; International Electrotechnical Commission: Geneva, Switzerland, 2014.

22. Kumar, S.; Iruthayarajan, M.W.; Bakrutheen, M.; Kannan, S.G. Effect of antioxidants on critical properties of natural esters for liquid insulations. IEEE Trans. Dielectr. Electr. Insul. 2016, 23, 2068-2078. [CrossRef]

23. Fofana, I. 50 years in the development of insulating liquids. IEEE Electr. Insul. Mag. 2013, 29, 13-25. [CrossRef]

24. Brázdil, J.; Černý, J.; Mentlík, V.; Trnka, P.; Košanová, L.; Kužílek, V. Biodegradable Electrical Insulating Fluid; Utility Model CZ 29 982; Industrial Property Office: Prague, Czech Republic, 2016.

25. Bin, D.; Li, J.; Wang, B.; Zhang, Z.T. Preparation and breakdown strength of $\mathrm{Fe}_{3} \mathrm{O}_{4}$ nanofluid based on transformer oil. In Proceedings of the 2012 International Conference on High Voltage Engineering and Application, Shanghai, China, 17-20 September 2012; pp. 311-313. [CrossRef]

26. Mergos, J.A.; Athanassopoulou, M.D.; Argyropoulos, T.G.; Dervos, C.T. Dielectric properties of nanopowder dispersions in paraffin oil. IEEE Trans. Dielectr. Electr. Insul. 2012, 19, 1502-1507. [CrossRef]

27. Das, S.K.; Choi, S.U.; Yu, W.; Pradeep, T. Nanofluids: Science and Technology; John Wiley \& Sons: Hoboken, NJ, USA, 2008; ISBN 13 978-0470074732.

28. Fuxin, W.; Ming, D.; Jianzhuo, D.; Ming, R.; Rixin, Y. Study of Breakdown Mechanism of Transformer Oil Based on ZnO Nanoparticles. In Proceedings of the International Symposium on High Voltage Engineering 2015, Pilsen, Czech Republic, 23-28 August 2015; pp. 1-4.

29. Putra, N.; Roetzel, W.; Das, S.K. Natural Convection of Nano-fluids. Heat Mass Transfer. 2003, 39, 775-784. [CrossRef]

30. Sima, W.X.; Cao, X.F.; Yang, Q.; Song, H.; Shi, J. Preparation of Three Transformer Oil-Based Nanofluids and Comparison of Their Impulse Breakdown Characteristics. Nanosci. Nanotechnol. Lett. 2014, 6, 250-256. [CrossRef]

31. Lv, Y.; Rafiq, M.; Li, C.; Shan, B. Study of Dielectric Breakdown Performance of Transformer Oil Based Magnetic Nanofluids. Energies 2017, 10, 1025. [CrossRef]

32. IEC. Insulating Liquids-Determination of the Breakdown Voltage at Power Frequency-Test Method; IEC 60156:1995; International Electrotechnical Commission: Geneva, Switzerland, 1995. 
33. Danikas, M.G.; Tanaka, T. Nanocomposites-a review of electrical treeing and breakdown. IEEE Electr. Insul. Mag. 2009, 25, 19-25. [CrossRef]

34. Jin, H.; Andritsch, T.; Tsekmes, I.A.; Kochetov, R.; Morshuis, P.H.F.; Smit, J.J. Properties of mineral oil based silica nanofluids. IEEE Trans. Dielectr. Electr. Insul. 2014, 19, 1100-1108. [CrossRef]

35. Du, Y.; Lv, Y.Z.; Li, C.; Chen, M.; Zhou, J.; Li, X.; Zhou, Y.; Tu, Y. Effect of electron shallow trap on breakdown performance of transformer oil-based nanofluids. J. Appl. Phys. 2011, 110. [CrossRef]

36. Jin, H.; Morshuis, P.H.F.; Smit, J.J.; Andritsch, T. The effect of surface treatment of silica nanoparticles on the breakdown strength of mineral oil. In Proceedings of the 2014 IEEE 18th International Conference on Dielectric Liquids, Bled, Slovenia, 29 June-3 July 2014; pp. 1-4. [CrossRef]

37. Du, Y.; Lv, Y.Z.; Wang, F.; Li, X.; Li, C. Effect of $\mathrm{TiO}_{2}$ nanoparticles on the breakdown strength of transformer oil. In Proceedings of the 2010 IEEE International Symposium on Electrical Insulation, San Diego, CA, USA, 6-9 June 2010; pp. 1-3. [CrossRef]

38. Zou, C.; Fothergill, J.; Rowe, S. The effect of water absorption on the dielectric properties of epoxy nanocomposites. IEEE Trans. Dielectr. Electr. Insul. 2008, 15, 106-117. [CrossRef]

39. Rafiq, M.; Lv, Y.; Li, C. A review on properties, opportunities, and challenges of transformer oil-based nanofluids. J. Nanomater. 2016, 2016, 1-23. [CrossRef]

40. Lewis, T.J. Interfaces: Nanometric dielectrics. J. Phys. D 2005, 38, 202-212. [CrossRef]

41. Tenbohlen, S.; Koch, M. Aging Performance and moisture solubility of vegetable oils for power transformers. IEEE Trans. Power Deliv. 2010, 25, 825-830. [CrossRef]

42. Dombek, G.; Goscinski, P.; Nadolny, Z. Comparison of mineral oil and esters as cooling liquids in high voltage transformer in aspect of environment protection. E3S Web Conf. 2017, 14, 01053. [CrossRef]

43. Smith, J.S.; Beaster, B.L. Design and test experience with natural ester fluid for power transformers update. In Proceedings of the 2009 IEEE Power \& Energy Society General Meeting, Calgary, AB, Canada, 26-30 July 2009. [CrossRef]

44. Fritsche, R.; Rimmele, U.; Schäfer, M. Prototype 420 kV Power Transformer Using Natural Ester Dielectric Fluid; Siemens, A.G.: Nuremberg, Germany, 2014.

45. Darwin, A.; Perrier, R.; Foliot, P. The use of natural ester fluids in transformer. In Proceedings of the MATPOST Conference, Lyon, France, 15-16 November 2007.

46. Bandara, K.; Ekanayake, C.; Saha, T.; Ma, H. Performance of Natural Ester as a Transformer Oil in Moisture-Rich Environments. Energies 2016, 9, 258. [CrossRef] 